\title{
PEMUTIHAN PULP DENGAN HIDROGEN PEROKSIDA
}

\author{
Ahmad M Fuadi $^{\left.{ }^{1 *}\right)}$ dan Hari Sulistya ${ }^{2)}$ \\ 1) Jurusan Teknik Kimia, Fakultas Teknik \\ Universitas Muhammadiyah Surakarta \\ Jl. A. Yani Tromol Pos 1 Pabelan Kartasura Surakarta Jawa Tengah 57102 \\ ${ }^{*}$ Penulis korespondensi : fuadi60@yahoo.com \\ ${ }^{2)}$ Jurusan Teknik Kimia, Fakultas Teknik UGM \\ Jalan Grafika 2, Kampus UGM, Yogyakarta \\ Telp: 0274-902171, fax: 0274-902170
}

\begin{abstract}
The use of bleaching agent has increased as the result of increasing of paper consumption. The conventional bleaching agent that commonly used is material containing of chlorine. This material is not environmentally friendly and should be replaced by environmentally benign chemical, such as $\mathrm{H}_{2} \mathrm{O}_{2}$. About 40 gram of dry Akasia pulp was mixed with $600 \mathrm{ml}$ of distilled water was put into plastic bag heated in a water bath. When the temperature reached $63^{\circ} \mathrm{C}$, a solution of $4 \%$ of $\mathrm{H}_{2} \mathrm{O}_{2}$ and distilled water was added to obtain $5 \%$ consistency. This mixture was put into water bath and was heated for 2 hours. The same procedure was conducted with various concentration of $\mathrm{H}_{2} \mathrm{O}_{2}$, time and $\mathrm{pH}$. At the end of the process, the pulp was dewatered and washed. The filtrate obtained from the initial dewatering was used to determine the residual of $\mathrm{H}_{2} \mathrm{O}_{2}$. The pulp was analyzed to determine brightness, fiber strength and kappa number. The maximum achievement of brightness was 62,1\% ISO, 6.86 of kappa number and $1.02 \mathrm{~kg} / 15 \mathrm{~mm}$ of fiber strength, which are reached at $16 \%$ of the use of $\mathrm{H}_{2} \mathrm{O}_{2}, \mathrm{pH} 11$ and 5 hours of bleaching time. This achievement is similar to bleaching result by the additional of $4 \% \mathrm{H}_{2} \mathrm{O}_{2}$. Inefficient usage of $\mathrm{H}_{2} \mathrm{O}_{2}$ was caused by some metal ions in the pulp which facilitate the decomposition of $\mathrm{H}_{2} \mathrm{O}_{2}$ to produce oxygen and water which has not effect on increasing the brightness. To improve the bleach ability of $\mathrm{H}_{2} \mathrm{O}_{2}$, initial treatment to remove metal ions from pulp should be done.
\end{abstract}

Key words: akasia, bleaching, hydrogen peroxide

\begin{abstract}
Abstrak
Seiring dengan meningkatnya kebutuhan kertas, kebutuhan bahan pemutih juga mengalami kenaikan. Saat ini bahan pemutih yang banyak digunakan adalah senyawa yang mengandung khlor. Senyawa ini sangat tidak ramah lingkungan, oleh karena itu, perlu dicari bahan yang ramah lingkungan untuk menggantikannya. Salah satunya adalah hidrogen peroksida. Pulp dari pohon akasia sebanyak 40 gram kering dicampur dengan $600 \mathrm{ml}$ aquadest dimasukkan dalam kantung plastik dipanaskan dalam water bath. Setelah suhu mencapai $63^{\circ} \mathrm{C}$, kantung plastik diambil kemudian ditambah hidrogen peroksida sebanyak 4\% dari pulp kering dan aquadest sehingga mencapai konsistensi 5\%. Campuran dimasukkan kedalam water bath untuk dipanaskan lebih lanjut hingga 2 jam. Hal yang sama dilakukan pada berbagai kadar hidrogen peroksida, waktu dan $p H$. Pada akhir proses, pulp dipisahkan dengan filtratnya dan dicuci dengan aquades. Filtrat yang diperoleh dianalisa sisa hidrogen peroksidanya. Pulp yang diperoleh dianalisa derajat putih, kekuatan serat serta bilangan kappanya. Maksimum derajat putih yang bisa dicapai adalah 62,1\% ISO, bilangan kappa 6,86 dan fiber strength $1,02 \mathrm{~kg} / 15 \mathrm{~mm}$ yang dicapai pada pemakaian $\mathrm{H}_{2} \mathrm{O}_{2} 16 \%$, pH 11 selama 5 jam. Pencapaian ini hampir sama dengan hasil yang dicapai ketika penambahan $\mathrm{H}_{2} \mathrm{O}_{2} 4 \%$. Ketidak efektifan pemakaian $\mathrm{H}_{2} \mathrm{O}_{2}$ disini disebabkan oleh adanya beberapa metal ion yang ada di dalam pulp yang bertindak sebagai katalisator terjadinya reaksi dekomposisi dari $\mathrm{H}_{2} \mathrm{O}_{2}$ membentuk oksigen dan air yang tidak efektif dalam memberikan efek terhadap proses pemutihan. Untuk meningkatkan bleach ability dari hydrogen peroksida, perlu dilakukan treatment awal untuk mengeluarkan metal ion dari pulp.
\end{abstract}

Kata kunci : akasia, pemutih, hidrogen peroksida 


\section{PENDAHULUAN}

Kebutuhan kertas terus mengalami kenaikan dari tahun ke tahun. Kenaikannya diperkirakan mencapai 3,5\% tiap tahun. Kenaikan yang terus menerus ini mengakibatkan kebutuhan bahan-bahan kimia yang terkait dengan proses pembuatan kertas juga mengalami kenaikan, salah satunya adalah bahan pemutih, yang diperkirakan pada tahun 2007 di Amerika Serikat saja kebutuhannya mencapai sekitar 12500 juta lb (Bayer et al, 1999). Saat ini bahan pemutih yang banyak digunakan dalam pemutihan pulp adalah senyawa yang mengandung khlor. Bahan yang mengandung khlor ini, merupakan bahan yang tidak ramah lingkungan. Oksidasi bahan organik oleh senyawa ini bisa menghasilkan senyawa-senyawa yang berbahaya seperti chloroform dan chloronitrometan. Khloroform merupakan racun bagi organ-organ fital seperti jantung, ginjal maupun hati. Khloroform telah dipastikan sebagai zat carcinogenic serta sangat beracun. Beberapa penelitian tentang dampak negatif dari pemakaian senyawa khlor pada proses pemutihan telah dilakukan. Coakley et al, (2001) melakukan penelitian untuk mengamati limbah bleaching pulp yang menggunakan $\mathrm{ClO}_{2}$. Limbah dikumpulkan dari berbagai jenis kayu menunjukkan semuanya mempunyai potensi mempengaruhi kehidupan ikan yang ada di sekitarnya. Daru (2002) melakukan kajian tentang reaksi samping yang terjadi pada proses pemutihan dengan menggunakan bahan yang mengandung khlorin. Khlorin akan bereaksi dengan senyawa organik dalam kayu membentuk senyawa toksik, misalnya dioksin. Dioksin ditemukan tidak hanya dalam air limbah, tapi dalam produk yang dihasilkan. Meskipun konsentrasi dioksin dalam air limbah sangat kecil tapi bila masuk dalam rantai makanan konsentrasinya akan menjadi berlipat karena adanya proses biomagnifikasi. Konsentrasi dioksin dari ikan yang ada di lingkungan ini konsentrasinya lebih tinggi daripada konsentrasi dioksin di sekitarnya. Nakatama et al, (2004) melakukan penelitian dengan mengukur kandungan khloroform yang ada di air limbah proses pemutihan dengan menggunakan $\mathrm{ClO}_{2}$. Hasilnya menunjukkan adanya khloroform di cairan maupun di udara sekitar proses. Mengingat betapa bahayanya proses pemutihan dengan bahan yang mengandung khlor, maka perlu dilakukan penelitianpenelitian untuk mencari alternatif pengganti senyawa khlor dengan senyawa yang ramah lingkungan, salah satunya hidrogen peroksida. Proses pemutihan tidak hanya meningkatkan derajat putih pulp, tetapi juga menaikkan kemurnian dan kesetabilannya. Meningkatnya derajat putih pulp ini disebabkan karena penghilangan lignin atau penghilangan warna lignin. Dalam pembuatan pulp, banyak lignin yang terlepas, ketika pulp ini kemudian diputihkan, maka pelepasan lignin berlanjut. Dengan adanya proses pemutihan, maka penggunaan kertas menjadi semakin luas. Salah satu efek samping dari proses pemutihan yang perlu diperhatikan adalah degradasi terhadap selulosa, karena hal ini akan menyebabkan menurunnya kekuatan serat yang mengakibatkan menurunnya kekuatan tarik kertas sebagai hasil akhir. Pelaksanaan pemutihan dilakukan dengan mencampur bahan kimia dengan pulp pada kondisi tertentu. Biasanya proses pemutihan dilakukan dalam beberapa tahap, setiap tahapan dilakukan proses pencucian sebelum dimasukkan ke tahap berikutnya.

\section{Kayu}

Komponen-komponen yang ada di kayu dapat dibedakan menjadi beberapa kelompok antara lain zatzat organik dengan berat molekul kecil, zat-zat organik dengan berat molekul besar serta zat-zat an organik. Zat-zat organik dengan berat molekul besar antara lain kelompok selulosa dan lignin. Selulosa adalah biopolimer yang paling banyak pada kayu, berkisar antara $40-45 \%$ dari material kering Derajat polimerisasi dari selulosa kayu diperkirakan 10.000 (Fengel and Wegner, 1989). Lignin adalah polimer tiga dimensi yang heterogen yang tersusun dari satuan-satuan phenylpropane, belum ditemukan stuktur kimia yang pasti dari lignin. Kandungan lignin dalam softwood lebih tinggi daripada dalam hardwood. Phenylpropane di softwood didominasi oleh tipe guiacylpropane sedang di hardwood ada dua tipe yaitu satuan-satuan guiacylpropane dan satuansatuan syringylpropane (Alder, 1977). Komponenkomponen lain dalam kayu yang larut dalam larutan organik netral atau air disebut ekstraktif. Beberapa diantaranya adalah lemak, lilin, terpena, terpenoid, stereoid, senyawa-senyawa fenol, protein dan kanji. Kandungan ekstraktif sekitar 4-10\% dari kayu kering yang mengumpul pada daerah tertentu (Sjöström, 1981). Total kandungan bahan-bahan anorganik dalam tumbuh-tumbuhan umumnya sangat kecil, serta tergantung dari asal tumbuh-tumbuhan itu tumbuh (Fengel and Wegner, 1989). Metal ion yang ada di kayu juga masih banyak terkandung di dalam pulp. Hal ini mempengaruhi efek pemutihan dengan menggunakan $\mathrm{H}_{2} \mathrm{O}_{2}$. Sumber utama pengotor metal ion di dalam proses pemutihan pulp adalah dari pulp itu sendiri. Tumbuh-tumbuhan, secara umum, membentuk metal ion dan kebutuhan makanan berasal dari sumber tanah di mana tumbuhan tersebut tumbuh, sehingga kandungan metal ionnya sangat tergantung dari lokasi dimana tumbuhan tersebut tumbuh.

\section{Hidrogen Peroksida}

Hidrogen peroksida termasuk zat oksidator yang bisa digunakan sebagai pemutih pulp yang ramah lingkungan. Di samping itu, hydrogen peroksida juga mempunyai beberapa kelebihan antara lain pulp yang diputihkan mempunyai ketahanan yang tinggi serta penurunan kekuatan serat sangat kecil. Pada kondisi asam, hidrogen peroksida sangat stabil, pada kondisi basa mudah terurai. Peruraian hidrogen peroksida juga dipercepat oleh naiknya suhu. Zat reaktif dalam sistem pemutihan dengan hidrogen peroksida dalam suasana basa adalah perhydroxyl anion (HOO-) (Dence and Reeve, 1996). 
Anion ini terbentuk dari penambahan alkali terhadap hidrogen peroksida sebagaimana persamaan (1) (Lachenal, 1996):

$$
\mathrm{HOOH}+\mathrm{HO}^{-} \leftrightarrow \mathrm{HOO}^{-}+\mathrm{H}_{2} \mathrm{O}
$$

Ion $\mathrm{HOO}^{-}$ini yang mempunyai peran aktif di dalam proses pemutihan, peruraian hidrogen peroksida sebagaimana persamaan (1) dikenal dengan deprotonation. Dengan adanya logam-logam transisi seperti $\mathrm{Fe}, \mathrm{Mn}$, dan $\mathrm{Cu}$, dekomposisi dari hydrogen peroksida dalam larutan basa dianggap berlangsung sebagaimana reaksi ionik berikut:

$$
\mathrm{H}_{2} \mathrm{O}_{2}+\mathrm{HO}_{2} \rightarrow \mathrm{H}_{2} \mathrm{O}+\mathrm{O}_{2}+\mathrm{HO}
$$

Logam-logam transisi bertindak sebagai katalis yang mengarahkan dekomposisi $\mathrm{H}_{2} \mathrm{O}_{2}$ mengikuti persamaan reaksi (2) (Duke, Haas 1961). Pada kondisi basa, dengan adanya katalisator, hasil-hasil dekomposisi hidrogen peroksida antara lain radikal-radikal anion hidroksil dan superoksid sebagai zat intermadiate sebagaimana persamaan (2) (Agnemo et al, 1979). Pada pemutihan dengan hidrogen peroksida diharapkan yang terjadi adalah persamaan reaksi (1), sedang reaksi dekomposisi yang disebabkan dari pengaruh katalis ion-ion logam transisi harus dicegah, karena tidak memberikan dampak yang efektif pada proses pemutihan (Brelid, 1998).

\section{Tujuan Penelitian}

Penelitian ini bertujuan untuk mengamati hasil yang dicapai selama proses pemutihan dengan menggunakan hidrogen peroksida tanpa treatment apapun.

\section{METODE PENELITIAN}

Bahan baku yang digunakan pada penelitian ini berupa pulp yang diperoleh dari PT Indah Kiat Pulp and Paper, dengan derajat putih 41,7\% ISO, bilangan Kappa 10,38 serta kuat tarik 1,15 kg/15mm, sedang hidrogen peroksida diperoleh dari PT PIP Tangerang dengan kadar sekitar 50\%.

\section{Cara Penelitian}

Pulp basah (70,89\% air) sebanyak 137,4 gram (40 gram kering) dicampur dengan $600 \mathrm{ml}$ aquadest dimasukkan dalam kantung plastik dipanaskan dalam waterbath. Setelah suhu mencapai $63^{\circ} \mathrm{C}$, kantung plastik diambil kemudian ditambah hidrogen peroksida sebanyak 4\% dari pulp kering dan aquadest sehingga mencapai konsistensi 5\%, dicampur hingga sempurna kemudian dimasukkan kedalam waterbath. Kondisi pemutihan dengan $\mathrm{H}_{2} \mathrm{O}_{2}$ umumnya dilakukan pada kisaran suhu antara $60^{\circ} \mathrm{C}$ hingga $80^{\circ} \mathrm{C}$ selama 30 menit hingga 180 menit (Dence and Reeve, 1996). Pada penelitian ini proses pemutihan dijalankan pada suhu $70^{\circ} \mathrm{C}$ selama 2 jam. Hal yang sama dilakukan pada berbagai kadar hidrogen peroksida (8\%, 12\%, dan 16\%) serta waktu (3 jam, 4 jam, dan 5 jam) dan $\mathrm{pH}$ (9,8 dan 11). Pada akhir proses, pulp dicuci dengan aquadest, kemudian dianalisa, sisa hidrogen peroksida, derajat putih, dan kekuatan serat serta bilangan kappa.

\section{Analisa Hasil}

Pengukuran derajat putih dan kekuatan serat dilakukan di Pabrik kertas Blabak Muntilan Jawa Tengah dengan cara membuat lembaran kertas kemudian diukur derajat putihnya dengan alat fotometer, sedang kuat tarik dilakukan dengan cara memotong lembaran kertas lebar $15 \mathrm{~mm}$, panjang 20 cm ditarik hingga putus kemudian dilihat bebannya. Analisa sisa hidrogen peroksida dilakukan dengan titrasi menggunakan $\mathrm{Na}_{2} \mathrm{~S}_{2} \mathrm{O}_{3}$. Aquades $(30 \mathrm{ml})$ dimasukkan dalam Erlenmeyer bersama-sama dengan $10 \mathrm{ml} \mathrm{H} \mathrm{SO}_{4}$ (20\%), $10 \mathrm{ml}$ sampel, $10 \mathrm{ml}$ larutan KI (50 g/L) serta beberapa tetes larutan ammonium molybdate jenuh (sebagai catalyst). Jika dalam sampel terdapat hidrogen peroksida, maka akan terbentuk iodine. Jumlah dari $\mathrm{I}_{2}$ dalam larutan ditentukan dengan titrasi menggunakan 0.1 molar $\mathrm{Na}_{2} \mathrm{~S}_{2} \mathrm{O}_{3}$. Konsentrasi $\mathrm{H}_{2} \mathrm{O}_{2}$ dalam sampel dapat ditentukan dengan:

$$
\begin{aligned}
& \mathrm{H}_{2} \mathrm{O}_{2} \mathrm{~g} / \mathrm{L}=\left[\mathrm{S}_{2} \mathrm{O}_{3}\right] * \frac{\mathrm{b} * 34}{\mathrm{a} * 2} \\
\text { dengan, } \mathrm{b}= & \text { volume } \mathrm{Na}_{2} \mathrm{~S}_{2} \mathrm{O}_{3}(\mathrm{ml}) \\
\mathrm{a}= & \text { volume sampel }(\mathrm{ml}) \\
\mathrm{S}_{2} \mathrm{O}_{3}{ }^{2}= & 0.1 \mathrm{M}
\end{aligned}
$$

Pulp (antara $0.5 \mathrm{~g}$ hingga $3 \mathrm{~g}$, tergantung pada perkiraan bilangan kappa) dimasukkan dalam glass beaker bersama-sama dengan $230 \mathrm{ml}$ aquadest. Campuran ini diblender untuk memisahkan serat-serat pulp, kemudian ditambahkan $25 \mathrm{ml} \mathrm{KMnO}_{4}(0.1 \mathrm{~N})$ dan $25 \mathrm{ml} \mathrm{H}_{2} \mathrm{SO}_{4}(2 \mathrm{M})$. Reaksi dijalankan pada $\mathrm{t}$ $25^{\circ} \mathrm{C}$. Setelah 10 menit, reaksi dihentikan dengan menambahkan $6 \mathrm{ml} \mathrm{KI} 1 \mathrm{M}$. Iodine yang terbentuk dititrasi dengan $0.1 \mathrm{M} \mathrm{Na}_{2} \mathrm{~S}_{2} \mathrm{O}_{3}$. Bilangan kappa dapat dihitung dengan:

$$
\text { Kappa }=\frac{(\mathrm{x}-\mathrm{y}) * \mathrm{~d}}{\mathrm{~m}}
$$

dengan, $\mathrm{x}=$ =volume (ml) $\quad \mathrm{Na}_{2} \mathrm{~S}_{2} \mathrm{O}_{3} \quad 0,1 \quad \mathrm{~N}$ yang dibutuhkan untuk titrasi blanko, $\mathrm{y}=$ volume (ml) $\mathrm{Na}_{2} \mathrm{~S}_{2} \mathrm{O}_{3}$ 0,1 $\mathrm{N}$ yang dibutuhkan untuk titrasi sampel, $\mathrm{m}=$ berat pulp kering (gram) $\mathrm{d}=$ factor koreksi, yang nilainya: $=10^{0,00093(\alpha / 0,3-50)}$

\section{HASIL DAN PEMBAHASAN}

Hasil yang diperoleh disajikan pada Tabel 1 . Berdasarkan data dari Tabel 1, hasil pemutihan yang dicapai dari pemutihan dengan $\mathrm{pH} 11$ tidak selalu lebih tinggi daripada hasil pemutihan pada $\mathrm{pH}$ 9,8, padahal pemakaian hidrogen peroksida pada $\mathrm{pH} 11$ jauh lebih banyak daripada pada $\mathrm{pH}$ 9,8. Hal ini disebabkan karena terjadinya dekomposisi hydrogen peroksida yang dipercepat dengan adanya metal ion di dalam pulp, sehingga sebagian besar $\mathrm{H}_{2} \mathrm{O}_{2}$ yang ditambahkan terdekomposisi menjadi air dan oksigen tanpa memberikan efek terhadap naiknya derajat putih. Hasil ini bisa dilihat pada Gambar 1 dan Gambar 2. 
Tabel 1. Data percobaan

\begin{tabular}{|c|c|c|c|c|c|c|c|c|c|c|c|c|c|c|c|c|c|}
\hline \multirow{2}{*}{$\mathrm{H}_{2} \mathrm{O}_{2}(\%)$} & \multirow{2}{*}{$\mathrm{pH}$} & \multicolumn{4}{|c|}{$\begin{array}{l}\text { Brightness, } \\
\text { \% ISO }\end{array}$} & \multicolumn{4}{|c|}{ Bilangan Kappa } & \multicolumn{4}{|c|}{$\begin{array}{c}\text { Fiber strength, } \\
\text { kg/15 mm }\end{array}$} & \multicolumn{4}{|c|}{$\begin{array}{c}\text { Pemakaian } \mathrm{H}_{2} \mathrm{O}_{2} \text {, } \\
\text { g }\end{array}$} \\
\hline & & $2 \mathrm{j}$ & $3 \mathrm{j}$ & $4 \mathrm{j}$ & $5 \mathrm{j}$ & $2 j$ & $3 \mathrm{j}$ & $4 j$ & $5 \mathrm{j}$ & $2 \mathrm{j}$ & $3 \mathrm{j}$ & $4 \mathrm{j}$ & $5 \mathrm{j}$ & $2 \mathrm{j}$ & $3 \mathrm{j}$ & $4 \mathrm{j}$ & $5 \mathrm{j}$ \\
\hline & 9,8 & 52,8 & 55,6 & 55,6 & 55,6 & 9,24 & 8,45 & 7,92 & 7,66 & 1,28 & 1,17 & 1,29 & 1,29 & 0,91 & 1,03 & 1,16 & 1,21 \\
\hline & 11 & 55,6 & 55,6 & 55,6 & 55,6 & 8,98 & 7,39 & 7,39 & 7,55 & 1,13 & 0,94 & 1,02 & 1,29 & 1,35 & 1,45 & 1,50 & 1,52 \\
\hline \multirow[b]{2}{*}{0} & 9,8 & 55,6 & 55,6 & 58,3 & 58,3 & 8,71 & 7,97 & 7,79 & 7,41 & 1,27 & 0,91 & 0,75 & 1,37 & 2,13 & 2,42 & 2,59 & 2,68 \\
\hline & 11 & 55,6 & 56,3 & 56,9 & 56,9 & 7,17 & 6,92 & 6,60 & 6,47 & 0,95 & 1,00 & 1,16 & 1,10 & 2,80 & 3,04 & 3,15 & 3,17 \\
\hline \multirow{2}{*}{1.} & 9,8 & 58,3 & 58,3 & 58,3 & 61,1 & 7,92 & 7,28 & 7,00 & 6,86 & 1,32 & 1,29 & 0,97 & 0,91 & 3,75 & 4,09 & 4,30 & 4,38 \\
\hline & 11 & 56,9 & 56,9 & 59,5 & 59,5 & 7,61 & 6,90 & 6,73 & 6,73 & 1,02 & 1,12 & 1,15 & 1,13 & 4,28 & 4,45 & 4,70 & 4,77 \\
\hline & 9,8 & 58,3 & 58,3 & 61,1 & 61,1 & 7,79 & 7,52 & 7,26 & 6,60 & 1,22 & 0,98 & 1,17 & 1,10 & 4,48 & 4,90 & 5,27 & 5,47 \\
\hline & 11 & 59,5 & 59,5 & 59,5 & 62,1 & 7,04 & 7,00 & 6,86 & 6,86 & 0,82 & 1,29 & 1,02 & 1,02 & 5,47 & 6,13 & 6,32 & 6,38 \\
\hline
\end{tabular}
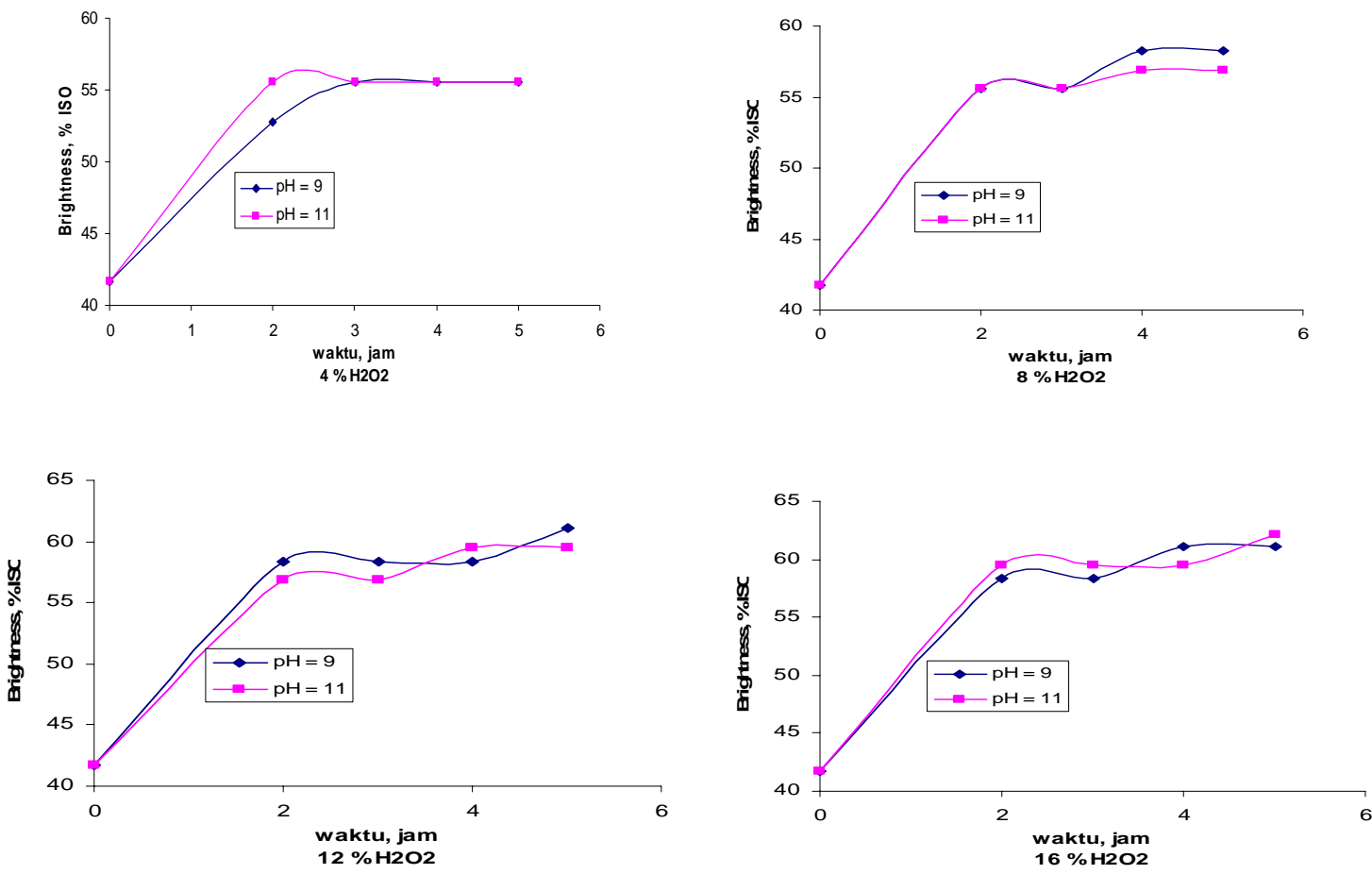

Gambar 1. Hubungan antara waktu pemutihan dengan brightness
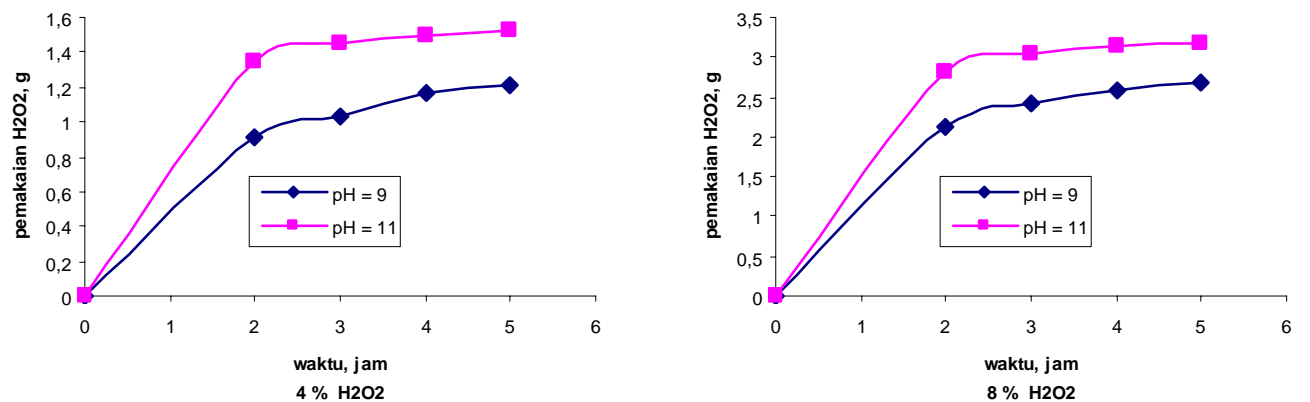

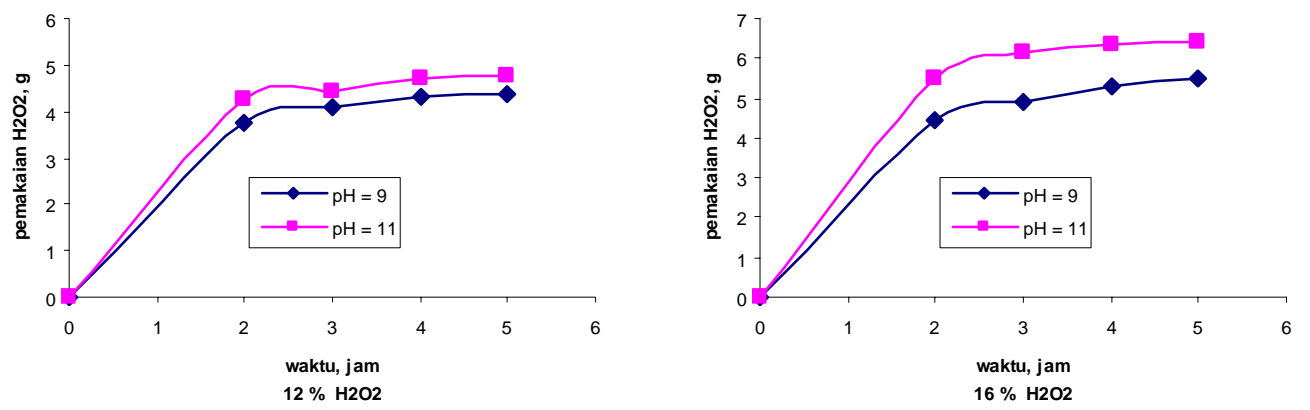

Gambar 2. Hubungan antara waktu pemutihan dengan pemakaian $\mathrm{H}_{2} \mathrm{O}_{2}$

Gambar 1 dan 2 menunjukkan bahwa kenaikan brightness yang bisa dicapai maximum 62,1\% ISO, yang dicapai pada pemakaian $\mathrm{H}_{2} \mathrm{O}_{2} 16 \%$. Kenaikan ini sangat kecil bila dibandingkan dengan brightness yang bisa dicapai pada pemakaian $\mathrm{H}_{2} \mathrm{O}_{2}$ 4\%. Padahal perbedaan $\mathrm{H}_{2} \mathrm{O}_{2}$ yang terpakai sangat jauh berbeda.

Jumlah $\mathrm{H}_{2} \mathrm{O}_{2}$ yang terpakai pada penambahan $\mathrm{H}_{2} \mathrm{O}_{2} 4 \%$ adalah 1,21 gram sedang pada penambahan $\mathrm{H}_{2} \mathrm{O}_{2} \quad 16 \%$ adalah 6,38 gram. Ketidakefektifan pemakaian $\mathrm{H}_{2} \mathrm{O}_{2}$ di sini disebabkan oleh adanya beberapa metal ions yang ada di dalam pulp (Fe, Mn dan $\mathrm{Cu}$ ) yang bertindak sebagai katalisator terjadinya reaksi sebagaimana persamaan reaksi 2 .

Pemakaian $\mathrm{H}_{2} \mathrm{O}_{2}$ meningkat dengan naiknya $\mathrm{pH}$, ini disebabkan karena dekomposisi $\mathrm{H}_{2} \mathrm{O}_{2}$ dipercepat dengan $\mathrm{pH}$. Di sisi lain, perhydroxyl anion $\left(\mathrm{HOO}^{-}\right)$yang memberikan efek terhadap pemutihan terbentuk dari penambahan alkali terhadap hidrogen peroksida sebagaimana persamaan (1). Dengan demikian pengendalian reaksi agar menuju reaksi (1) sangat penting. Ini bisa dilakukan dengan mengambil ion - ion logam (sebelum proses pemutihan) yang ada di dalam pulp yang bertidak sebagai katalisator terhadap dekomposisi $\mathrm{H}_{2} \mathrm{O}_{2}$. Kandungan lignin dalam pulp sangat erat hubungannya dengan bilangan kappa. Ini didasarkan pada prinsip bahwa lignin akan menkonsumsi kalium permanganat dengan kecepatan yang jauh lebih tinggi daripada komponen-komponen karbohidrat di dalam pulp. Sehingga penggunaan kalium permanganat bisa digunakan untuk mengukur kandungan lignin didalam pulp. Kandungan lignin di dalam pulp semakin rendah dengan rendahnya bilangan kappa. Meningkatnya brightness berarti menurunnya kadar lignin di dalam pulp yang berarti juga menurunnya bilangan kappa. Hubungan antara brightness dengan bilangan kappa disajikan di Gambar 3.

Pada pengukuran fiber strength diperoleh harga yang sangat berfluktuasi, hal ini disebabkan karena sulitnya mendapatkan kondisi yang seragam yaitu ketebalan lembaran kertas yang diuji dalam setiap pengujian. Perbedaan ketebalan lembaran kertas ini akan mempengaruhi kuat tarik kertas. Kekuatan kertas sangat dipengaruhi oleh panjang serat. Semakin panjang seratnya kekuatan kertas yang dihasilkan juga semakin kuat. Panjang serat berhubungan dengan viskositas larutan serat. Sehingga fiber strength bisa diukur secara tidak langsung dengan mengukur viskositas larutan pulp. Semakin tinggi viscositasnya berarti derajat polimerisasi seratnya juga semakin tinggi yang berarti pula kekuatan seratnya semakin tinggi pula.

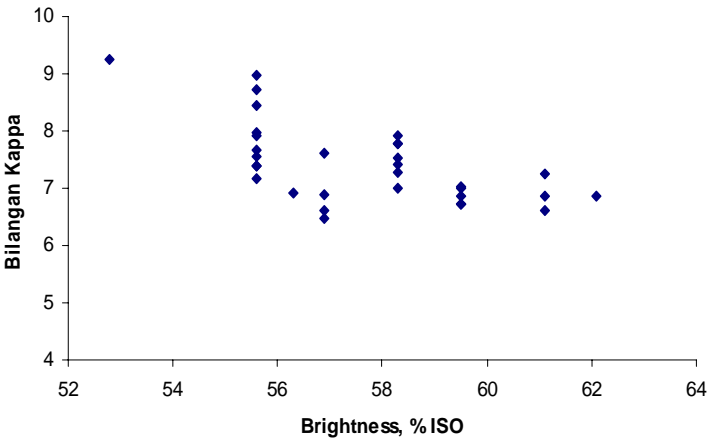

Gambar 3. Hubungan antara bilangan kappa dan brightness

\section{KESIMPULAN}

Peningkatan derajat putih pada berbagai penambahan bleaching agent $\left(\mathrm{H}_{2} \mathrm{O}_{2}\right)$ tidak menunjukkan perbedaan yang berarti, bahkan peningkatannya kecil. Hal ini disebabkan karena pengaruh beberapa metal ions yang ada di dalam pulp yang mempengaruhi keefektifan $\mathrm{H}_{2} \mathrm{O}_{2}$ sebagai pemutih. Untuk meningkatkan bleach ability hidrogen peroksida, perlu dilakukan treatment awal untuk melepaskan metal ions yang ada di dalam pulp. Penambahan $\mathrm{NaOH}$ sebagai sumber $[\mathrm{OH}]$ pada persamaan reaksi (1) sangat diperlukan, akan tetapi perlu juga dipertimbangkan bahwa pada $\mathrm{pH}$ yang tinggi $\mathrm{H}_{2} \mathrm{O}_{2}$ mudah terdekomposisi sebagaimana persamaan reaksi (2) yang tidak memberikan efek terhadap meningkatnya derajat putih. Hal ini terlihat dengan semakin banyaknya $\mathrm{H}_{2} \mathrm{O}_{2}$ yang terpakai ketika proses pemutihan dijalankan pada $\mathrm{pH} 11$, namun tidak menunjukkan kenaikan brightness yang berarti. Sebagaimana ditunjukkan pada Tabel 1. Untuk itu perlu mencari kondisi $\mathrm{pH}$ yang optimum untuk proses pemutihan. 


\section{DAFTAR PUSTAKA}

Agnemo, R., Gellerstedt, G., and Lindfors, E.L., (1979), Acta Chem.Scand, B. 33:2,154

Alder, E., (1977), Wood Sci. Technol, 11, 169-218.

Bayer, J., Dilme, and Fernandez-Zapico, J.M., (1999), Tendenciaous on in Industria Papelera en Los Inicious del Singlo XXI IngeneriaQuimico 3, 177-181

Brelid, H., (1998), TCF Bleaching of Soft wood Kraft Pulp, Dissertation, Chalmers University of Technology Gotenberg, Sweden.

Coakley, J., Hondsen, P.V., Heiningen, A.V., and Cross, T., (2001), MFO Induction in Fish By Filtrates From Chlorine Dioxide Bleaching of Wood Pulp, Wat.Res., 35, 921-928.

Daru, S.R., (2002), Minimasi Limbah Dalam Industri Pulp dan Kertas, www.terranet.or.id
Dence, C.W., and Reeve, D.W., (1996), Pulp Bleaching Principle and Practice, Tappi Perss, Atlanta, Page:349-415.

Duke, F.R., and Haas, T.W., (1961), J. Phys.Chem., 65:2, 304.

Fengel, D., and Wegener, G., (1983), Wood: Chemistry, Ultrastructure, Reaction, ed.1, Gadjah Mada University Perss, Jogjakarta

Lachenal, D., (1996), in pulp bleaching, Dence, C.W., and Reeve, D.W., Eds., TAPPI PRESS, Atlanta, pp. 347-361.

Nakatama, K., Motoe, Y., and Ohi, H., (2004), Evaluation of Chloroform Formed in Process of Kraft Pulp Bleaching Mil Using Chlorine Dioxide, J. Wood Sci., 50, 242-247.

Sjostrom, E., (1981), Wood Chemistry, Fundamental and Application, Academic Press, New York, London. 